\title{
Monitoring System of The Temperature for Mini Fish Storage using Internet of Things
}

\author{
Eko Prayetno ${ }^{1 *}$, Tonny Suhendra ${ }^{1}$, Jeremya Lukmanto Saputra ${ }^{1}$ \\ ${ }^{1}$ Raja Ali Haji Maritime University, Engineering Faculty, 29124 Tanjungpinang, Indonesia
}

\begin{abstract}
Fish is one of the high-protein foods that are very helpful for the development of the human brain. Then, it is necessary to maintain the freshness of the fish for consumption. At this time, fishers and fishmongers preserve the freshness of fish by using Ice in the fish storage. However, it is considered ineffective due to improper ice change time. Therefore, monitoring temperature is very important and helpful to find the right time when replacing the Ice used to ensure the quality of fish. The development of this device uses Arduino ESP32, DHT21 Sensor, Micro SD Module, Internet of Things system, monitoring using Blynk Application and notifications using Telegram App. DHT21 sensor test results obtained a data conformity level (Error Level) of 2\%. At the fish storage room temperature, there is the lowest temperature of $10.50{ }^{\circ} \mathrm{C}$ and ice temperature conditions in the storage of $0{ }^{\circ} \mathrm{C}$. Therefore, the best state to keep fish fresh that researchers want is $0{ }^{\circ} \mathrm{C}$ to $2{ }^{\circ} \mathrm{C}$ at ice temperatures or $11.50{ }^{\circ} \mathrm{C}$ obtained in testing the time it takes to replace Ice by about 10 hours.
\end{abstract}

Keyword: Fish Storage, Monitoring System, Telegram, Temperature

\section{Introduction}

Fish is one of the high-protein foods that help the development of the human brain. To maintain the freshness of the fish to be consumed, the fish storage process must be as well as possible. Unfortunately, modern fish storage containers are pretty expensive, and users only use a container filled with ice cubes as a cooler to keep the fish fresh for a few days.

Conventional fish storage that exists today has several drawbacks. One of the drawbacks is when the user wants to know the stored ice supply. Stored ice supplies will affect the temperature, humidity, and quality of the fish. Currently, users have to look directly into the fish storage area to find out the stock of Ice stored. The checks carried out are less effective because they are time-consuming and coupled with limited human memory, which often forgets, causing the quality of the fish to be poor.

In research [1], an automatic control system for a fish cooler with a constant temperature. Research tools consist of a heatsink, Peltier, temperature gauge, and pump. The device, which is the system in this study, uses a temperature sensor and Bluetooth. In this study, the user also has to pay quite a lot of money, and the monitoring system designed with Bluetooth media has shortcomings in terms of distance. Therefore, it is necessary to create a more efficient automatic monitoring system. Many modern technology designs make it possible to develop practical solutions to develop more flexible automated monitoring systems, one of which is using the Internet of Things (IoT). IoT technology is a plug-and-play technology that provides end-users ease of operation, remote access control, and configuration. IoT is a statistical/architectural trend widely used today and is a prospect for the future [2]. IoT data can be a rich source of evidence in dealing with various formal and informal issues, multitenant cloud infrastructure, and generating multi-jurisdictional litigation [3].

Research [4] about monitoring basic needs using an android-based microcontroller and a monitoring system using the Internet of Things (IoT). The data generated by the load cell sensor and the limit switch will be processed by Arduino and sent to the Thingspeak website. The sending data from Arduino to Thingspeak via Ethernet Shield and a router connected to the internet using a modem, then monitored using an Android smartphone. Research [5] designed an IoT-based room security system using an android application; this system works using several modules, including an RFID (Radio Frequency Identification) module, a camera module, and a door lock solenoid. In research [6], the Internet of Things (IoT) based PLTD Engine Oil Tank Volume Monitoring System, Using ESP8266 as a microcontroller and HC-SR04 Ultrasonic Sensor to determine the oil volume. The process of sending data from Arduino to ThingSpeak using the Blynk

\footnotetext{
* Corresponding author: ekoprayetno@umrah.ac.id
} 
application. Then, lamp monitoring system using IoTbased Nodemcu Amica cp2102 microcontroller [7].

Based on this background, in this study, the researchers designed a temperature and humidity monitoring tool for mini fish storage using temperature sensors and humidity sensors based on the Internet of Things. Detailed design will explain in the research method.

\section{Research Method}

The data collection method used in this study is observation and interviews. First, observations and direct interviews were conduct to seek information from fishers and sellers to determine how long it takes to change the Ice in the fish storage area. In addition, direct observations and interviews to assess the user background to implement the designed device directly.

This study begins with the design of several inputs, namely temperature sensors and humidity sensors, to detect the condition of fish storage areas. The freshness of fish is crucial in determining the overall quality of a fishery product. Moreover, the speed of fish rot is mainly affected by temperature [8].

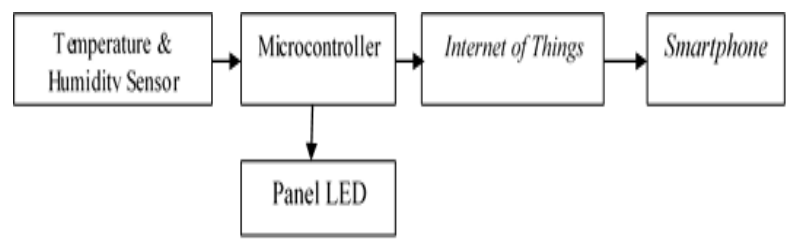

Figure 1. Device System Design

The microcontroller will process the input data channel to the LED panel and the Internet of Things. The output data is monitor using a Smartphone. The workings of the device, starting with the temperature sensor and humidity sensor detecting the room where the fish store, after both sensors receive the condition of the room where the fish store, then processed by the microcontroller which released on the led panel. Then the data from the temperature and humidity results are stored by Micro SD (Figure 1).

The microcontroller will also process data if the temperature in the storage room is below 12 degrees Celsius. The microcontroller will start from the beginning to detect the temperature and humidity of the room where the fish store. Suppose the temperature is above 12 degrees Celsius.

\section{Results and Discussion}

In the implementation of the device, the storage area used is a box made of styrofoam cork that can maintain the temperature inside the storage so that it is not affected by the temperature from outside the storage area. The physical shape of the storage parts used styrofoam cork with dimensions of $40 \mathrm{~cm}$ long, $30 \mathrm{~cm}$ wide, and $15 \mathrm{~cm}$ high. The sensor temperature and humidity position are in the bottom cover storage area.

The software discussion will explain the Listing program used in the Small Size Fish Storage
Temperature and Humidity (Figure 2). Monitoring tool using IoT. The first used library is the Serial BLYNK_PRINT connecting to the Blynk app. The second library $<$ DHT.h $>$ uses DHT sensors on the program. The third library $<$ FS.h $>$ serves to include all related programs on the system. The fourth library $<$ SD.h $>$ Connect sd card in the program. The fifth library $<$ SPI.h $>$ is a dedicated library tasked with handling SPI sync serial communication (Serial Peripheral Interface). The sixth library $<$ WiFi.h $>$ Connect WiFi In The seventh Program Library $<$ WiFiClientSecure.h $>$ create $\mathrm{WiFi}$ on the program to be accessible bias on the system used. The eighth library $<$ BlynkSimpleESP32.h $>$ is the board to use on the agenda. The ninth library <UniversalTelegrambot.h $>$ connects bots on telegrams on the system. The tenth library $<$ NTPClient.h $>$ serves to access the time on the program. The eleventh library $<$ Wire.h $>$ helps to connect led wires to the program. The twelfth library $<$ LiquidCrystal_I2C.h $>$ serves to connect the LCD in the program to be systemized, i.e., the display on the LCD.

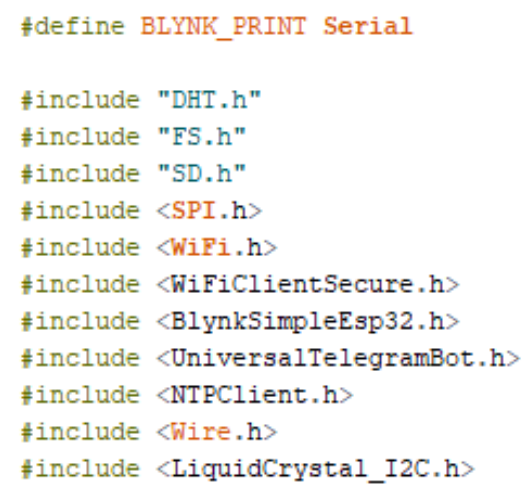

Figure 2. Library

The results of the testing data of mini-size fish storage equipment began with testing using a fish storage place made of Styrofoam cork with a size to withstand the cold temperatures inside the storage area. The storage area fills with Tamban fish and Ice made from seawater. The sensor is placed under the lid of the storage area because in order not exposed to Ice or water produced. The sensor used is a DHT sensor which has a relatively good level of precision [9]. The tool to monitor the temperature using the Blynk application to know the lowest temperature in the fish storage. The lowest temperature value displayed is about $10.50{ }^{\circ} \mathrm{C}$. Then before the actual data collection, it is necessary to calibrate the device that design. The calibration process is vital so that the resulting data is of high quality and close to the truth [10].

In this study, to periodically maintain the temperature, it must be below $12^{\circ} \mathrm{C}$. The temperature of $12{ }^{\circ} \mathrm{C}$ in hollow space is equal to $0{ }^{\circ} \mathrm{C}$ in ice water. This condition corresponds to the ideal temperature of the fish storage area, which is between $-2^{\circ} \mathrm{C}$ to $0^{\circ} \mathrm{C}[11]$. The tool will send a notification to remind you at a particular time when adding Ice and throwing water in the fish storage through the telegram application. The time required to raise the temperature to $12{ }^{\circ} \mathrm{C}$ is about 10 hours (Table 1). Data collection found some differences 
in data between the sensor and temperature measuring device with an error of $2 \%$. Therefore, the calibration process aims to get the closest value, as described in the study [10].

Blynk monitoring testing uses the Blynk application. Researchers showed the amount of temperature and humidity on the sensors. Blynk can be accessed if the ESP32 module is connected to the internet and successfully connected to a smartphone (Figure 3 ). The advantage of ESP32 is that it can process data using programming and with IoT technology [12]. It has connected to the smartphone, and then there is a microcontroller notification already related. If it is disconnected, there is also a notification that the microcontroller has a disconnect.

Table 1. Temperature-compare

\begin{tabular}{|c|c|c|c|c|c|}
\hline & \multicolumn{5}{|c|}{ The temperature in Ice $\left({ }^{\mathbf{0}} \mathbf{C}\right)$} \\
\cline { 2 - 6 } & $\mathbf{0}$ & $\mathbf{0 . 5}$ & $\mathbf{1}$ & $\mathbf{1 . 5}$ & $\mathbf{2}$ \\
\hline \multirow{4}{*}{$\begin{array}{c}\text { Sensor } \\
\text { temperature } \\
\text { on the device } \\
\text { (Hollow }\end{array}$} & 10.50 & 10.70 & 11 & 11.20 & 11.50 \\
\cline { 2 - 6 } & 10.50 & 10.70 & 11 & 11.30 & 11.50 \\
\cline { 2 - 6 } Space) $\left({ }^{\circ} \mathbf{C}\right)$ & 10.50 & 10.70 & 10.9 & 11.20 & 11.50 \\
\cline { 2 - 6 } & 10.60 & 10.70 & 11 & 11.20 & 11.60 \\
\cline { 2 - 6 } & 10.50 & 10.80 & 11 & 11.20 & 11.50 \\
\cline { 2 - 6 } & 10.50 & 10.70 & 11 & 11.20 & 11.50 \\
\cline { 2 - 6 } & 10.60 & 10.80 & 11 & 11.20 & 11.40 \\
\cline { 2 - 6 } & 10.50 & 10.70 & 11 & 11.20 & 11.50 \\
\cline { 2 - 6 } & 10.50 & 10.70 & 11 & 11.20 & 11.50 \\
\hline
\end{tabular}

Researchers displayed temperatures in tests using the telegram app to notify changes in the set upper temperature. Telegram is one of the most promising messaging applications today [13]. In the previous studies, the telegram application's monitoring system in measuring temperature was quite effective [14][15]. The telegram app can be accessed by following @ TemHummBot accounts on telegrams and internetconnected ESP32 modules. First, the temperature is set and wants to be displayed, and then automatically, the account@TemHummBot will give a message to the users of the telegram application (Figure 4).

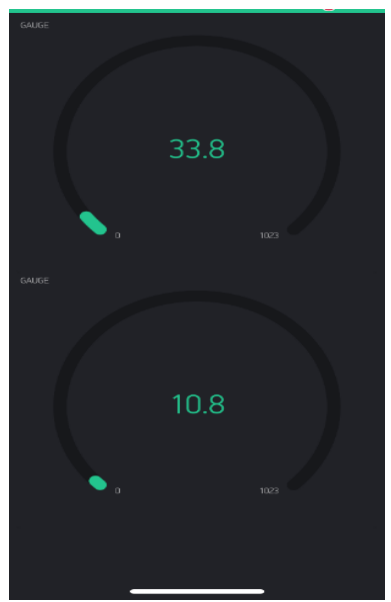

Figure 3. Application Blynk

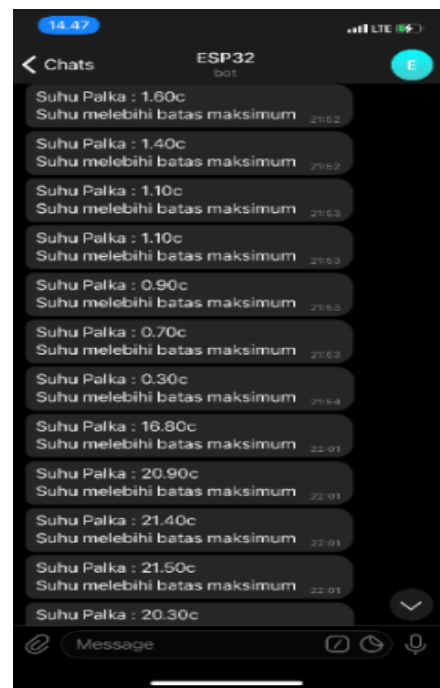

Figure 4. Application Telegram

\section{Conclusion}

The temperature and humidity monitoring device for fish storage using IoT has been successfully designed based on the test results. This tool can accurately measure the temperature and humidity of mini-size fish storage. Therefore, the study results can formulate that the temperature obtained by the dht 21 sensor averages the percentage of error $2 \%$. The comparison of the storage room temperature and Ice temperature is $10.50^{\circ} \mathrm{C}$ room for $0^{\circ} \mathrm{C}$ on Ice. Then monitoring Blynk and telegram applications run optimally and affect the connection that has.

\section{Acknowledgment}

Praise and gratitude the author pray to the presence of God Almighty; the author can complete this research. Thanks also to Raja Ali Haji Maritime University for the support provided.

\section{References}

1. Eviyanti, G. N., Prayetno, E., \& Prayetno, E. (2019). Automatic Control Systems for Fish Box Cooler. International Journal of Electrical, Energy and Power System Engineering, 2(1), 1-5. DOI: 10.31258/ijeepse.2.1.1-5

2. K. Shafique, B. A. Khawaja, F. Sabir, S. Qazi, and M. Mustaqim, "Internet of Things (IoT) for NextGeneration Smart Systems: A Review of Current Challenges, Future Trends and Prospects for Emerging 5G-IoT Scenarios," in IEEE Access, vol. 8, pp. 23022-23040, 2020, DOI: 10.1109/ACCESS.2020.2970118.

3. M. Stoyanova, Y. Nikoloudakis, S. Panagiotakis, E. Pallis, and E. K. Markakis, "A Survey on the Internet of Things (IoT) Forensics: Challenges, Approaches, and Open Issues," in IEEE Communications Surveys \& Tutorials, vol. 22, no. 
2, pp. 1191-1221, Second quarter 2020, DOI: 10.1109/COMST.2019.2962586.

4. Danang Ade Muktiawan \& Nurfiana Nurfiana(2018). Primary Needs Storage Monitoring System. Journal of Information Systems and Telematics, Vol.9, No. 1, pp.88-98.

5. Kristomson H, Rosalia H, Subrata H, Ferrianto Gozali. (2018). Internet Of Things Based Room Security System Using Applications. Vol 20, No 2, pp.127-134.

6. E. Prayetno, T. Nadapdap, A. S. Susanti, and D. Miranda, "PLTD Engine Tank Oil Volume Monitoring System using HC-SR04 Ultrasonic Sensor Based on Internet of Things (IoT)", IJEEPSE, vol. 4, no. 1, pp. 134-138, Feb. 2021.

7. Randu Apriza Dirni, 2021, Internet Of Things (IoT) Remote Light Control System Using Mobile Based Nodemcu Amica CP2102, Journal of Electrical Engineering ITP, Vol 10, No 2.

8. Christina Litaay, Sugeng Hari Wisudo, John Haluan, Bambang Harianto, (2017). Effect of Differences in Cooling Methods and Storage Time on Organoleptic Quality of Fresh Skipjack Fish. Journal of Tropical Marine Science and Technology Vol. 9 No. December 2, 2017, 717726.

9. Yoga Alif Kurnia Utama, Yonatan Widianto, Trie Arief Sardjono, Hendra Kusuma, 2019, Comparison Of Quality Between Air Humidity Sensors Using Arduino Uno. Procedure Of The National Seminar Of Science And Technology Snst, Vol 1, No 1 (2019), Pp. 60-65

10. Heaton, T., Blaauw, M., Blackwell, P., Bronk Ramsey, C., Reimer, P., \& Scott, E. 2020. The IntCal20 Approach to Radiocarbon Calibration Curve Construction: A New Methodology Using Bayesian Splines and Errors-in-Variables. Radiocarbon, Vol 62, No 4, Pp 821-863

11. Risa Setyalina, Shanti Kartika Sari, Design And Analysis Of Cool Box As A Fish Storage Media For Fishers In The Lumpur Region, Gresik Regency. National Seminar On Applied Science And Technology Vi 2018, Adhi Tama Institute Of Technology Surabaya, Pp. 193-198.

12. Hilmansyah, Restu Mukti Utomo, Angga Wahyu Saputra, Reva Fauzan Ali, 2020, Design And Construction Of Wireless Battery Monitoring System Based On Esp32. Snitt- Politeknik Negeri Balikpapan, Pp 194-199.

13. Ivan M. Tsidylo, Sergiy I. Samborskiy, StanislavIvan V. Mazur, Maria P. Zamoroz, 2020. Design a chatbot for learning a subject in a Telegram messenger. Proceedings of the 16th International Conference on ICT in Education, Research and Industrial Applications. Integration, Harmonization, and Knowledge Transfer. Volume II: Workshops (ICTERI 2020) Kharkiv, Ukraine.

14. R. E. N. Sisyanto, Suhardi, N. B. Kurniawan, "Hydroponic smart farming using a cyber-physical social system with telegram messenger. 2017
International Conference on Information Technology Systems and Innovation (ICITSI), pp. 239-245.

15. Hariyanto, M., Hendri Hendrawan, A., \& Ritzkal, R. 2020. Monitoring the Environmental Temperature of the Arduino Assistance Engineering Faculty Using Telegram. Journal of Robotics and Control (JRC), 1(3), 96-101. 